\title{
Preemptive analgesic efficacy of dexketoprofen trometamol on impacted third molar surgery
}

\author{
Gömülï̈ üçüncü molar diş cerrahisinde deksketoprofen trometamol'un \\ preemptif analjezik etkinliği
}

\author{
Esra ÇAĞIRAN, ${ }^{1}$ Can EYIGÖR, ${ }^{2}$ Bahar SEZER, ${ }^{3}$ Meltem UYAR ${ }^{2}$
}

\begin{abstract}
Summary
Objectives: The aim of this study was to compare the pre-emptive analgesic efficacy of intravenous (IV) dexketoprofen trometamol (DT) and placebo, following impacted mandibular third molar surgery.

Methods: Twenty patients over 18 year old who needed bilateral lower third molar extractions were included in this prospective, randomized and placebo-controlled clinical trial. Patients whom had taken DT $50 \mathrm{mg}$ of before their one extraction, took placebo before their other extraction which had been performed on the opposite side. A total of 40 observations were made. Pain scores were evaluated with a Verbal Rating Scale (VRS) after surgery. Moreover; the time to first analgesic requirement use, additional analgesic need of patients, patient and doctor satisfaction, side effects were also determined.

Results: During the first 12 hours, the VRS values in DT group were significantly lower than those of placebo group patients $(\mathrm{p}<0.05)$. In placebo group, the time to first analgesic requirement use was significantly earlier than that of patients in DT group $(p<0.05)$. Additional analgesic need of placebo group were significantly greater, when compared with the analgesic need of DT group patients $(\mathrm{p}<0.05)$. Among the DT group patients, patient and physician satisfaction was greater, which was statistically significant $(\mathrm{p}<0.05)$.

Conclusion: Preemptive use of IV DT is more effective than placebo for using as preemptive analgesia for acute postoperative pain control in patients underwent removal of an impacted mandibular third molar surgery.
\end{abstract}

Key words: Dexketoprofen trometamol; impacted third molar surgery; preemptive analgesia.

Özet

Amaç: Bu çalışmada, intravenöz (IV) deksketoprofen trometamol’ün (DT) gömük üçüncü molar diş cerrabisindeki preemptif analjezik etkinliğinin plasebo grubuyla karşılaştırılması amaçlandı.

Gereç ve Yöntem: İki tarafl gömük diş çekimi yapilacak 18 yaş üzerinde 20 basta ileriye dönük, randomize, plasebo kontrollü çalışmaya alındı. Bir diş çekiminde $50 \mathrm{mg} D$ T alan hastaya diğer diş çekiminde plasebo uygulandı. Toplam 40 gözlem yapıldı. Ağrr skorları cerrahi sonrası Sözel Ağrı Skalası (VRS) ile değerlendirildi. Ayrıca ilk analjezik alma zamanı, ek analjezik ibtiyacı olan hastalar, basta ve bekim memnuniyeti, yan etkiler kaydedildi.

Bulgular: İlk 12 saat içinde VRS skoru DT grubunda plasebo grubuna göre anlaml olarak daba düşüktü ( $p<0.05)$. İlk analjezik ibtiyace plasebo grubunda DT grubuna oranla istatistiksel olarak anlamle daba erken oldu $(p<0.05)$. Plasebo grubundaki hastalarin ek analjezik ibtiyacı DT alan hastalara oranla istatistiksel olarak anlaml daha fazlaydı $(p<0.05)$. DT grubunda hasta ve bekim memnuniyeti istatistiksel olarak daha fazlayd $(p<0.05)$.

Sonuç: Üçüncü molar diş cerrabisinde preemptif IV DT kullanımının plaseboya oranla çok daba etkin ameliyat sonrası analjezi să̆ladı̆̆ını saptadık.

Anahtar sözcükler: Deksketoprofen trometamol; gömülü üçüncü molar diş cerrahisi; preemptif analjezi.

\footnotetext{
'Department of Anaesthesiology and Reanimation, Ege University Faculty of Medicine, Izmir; ${ }^{2}$ Department of Anaesthesiology and Reanimation, Pain Clinic, Ege University Faculty of Medicine, Izmir; ${ }^{3}$ Department of Oral and Maxillofacial Surgery, Ege University Faculty of Dentistry, Izmir, Turkey ${ }^{\prime}$ Ege Üniversitesi Tıp Fakultesi, Anesteziyoloji ve Reanimasyon Anabilim Dalı, Izmir;

${ }^{2}$ Ege Üniversitesi Tıp Fakultesi, Anesteziyoloji ve Reanimasyon Anabilim Dalı, Algoloji Bilim Dalı, Izmir;

${ }^{3}$ Ege Üniversitesi Diş Hekimliği Fakultesi, Ağız Diş ve Çene Cerrahisi Anabilim Dalı, İzmir

Submitted (Başvuru tarihi) 03.10.2012 Accepted after revision (Düzeltme sonrası kabul tarihi) 25.12.2012
}

Correspondence (İletişim): Dr. Esra Çăgıran. Ege Üniversitesi Tıp Fakültesi, Anesteziyoloji ve Reanimasyon Anabilim Dalı, İzmir, Turkey.

Tel: +90 - 232 - 3902142 e-mail (e-posta): esrayuksel73@yahoo.com 


\section{Introduction}

Most clinicians are faced with patients suffering from acute pain after surgical treatment. In order to treat postoperative pain, Crile developed the concept of preemptive analgesia in $1913 .^{[1]}$

Preemptive analgesia has been shown that analgesics given before the injury decrease central sensitization and therefore postoperative pain very significantly in comparison to the analgesics given after the injury. The effect of the preemptive analgesia is to prevent or reduce the development of any "memory" of the pain stimulus in the nervous system. ${ }^{[2]}$

Dexketoprofen trometamol (DT) is a non-steroidal anti-inflammatory drug (NSAID) with analgesic, anti-inflammatory and antipyretic actions belonging to the 2-arylpropionic acid family. Dexketoprofen is the $S(+)$ enantiomer of the racemic compound ketoprofen. ${ }^{[3]}$

DT that has demonstrated a good analgesic efficacy and a good safety profile in different acute and chronic painful conditions administered by oral route. ${ }^{[4-7]}$ Jiménez et al. ${ }^{[8]}$ reported that oral DT administration is effective in reducing pain after impacted mandibular third molar removal better than ibuprofen.

A parenteral formulation of DT for intravenous and intramuscular administration has been developed and recently marketed, showing good results in both efficacy and safety evaluations in renal colic ${ }^{[9]}$ and in postoperative pain. ${ }^{[3,10]}$

The objective of this study was to compare the efficacy of intravenous (IV) DT given before surgical extraction of an impacted mandibular third molar under local anesthesia.

\section{Materials and Methods}

This study was carried out in the Department of Oral and Maxillofacial Surgery of the Faculty of Dentistry of Ege University, following the approval of the Ethics Committe of Ege University Faculty of Medicine. All subjects were informed of the possible risks of oral surgery and treatments used. Each patient accepted and signed an informed consent form. This prospective, placebo-controlled, randomized study compared the effects of IV DT and placebo on postoperative pain control after third molar surgery. All patients were of American Society of Anesthesiologists (ASA) status I or II over 18 years old and had bilateral impacted mandibular third molars based on orthopantomogram evidence.

Patients who used analgesics for other reasons in the past 24 hours, had drug allergy, hepatic insufficiency, renal insufficiency, bleeding diathesis or gastrointestinal system complaints and pregnant patients were excluded from the study.

\section{Study design}

This was a crossover within-subject study and the patient would be pretreated with $0.9 \%$ isotonic saline solution or $50 \mathrm{mg}$ IV DT for the bilateral third molar surgeries in the same patient according to a randomization schedule.

In groups placebo and DT, randomly selected drugs administered consecutively to same 20 patient population group before the third molar teeth extractions which had been made 15 days apart. The drugs were disvolved in $100 \mathrm{ml}$ of $0.9 \%$ isotonic saline solution and then administered via IV infusion in $15 \mathrm{~min}$. After $15 \mathrm{~min}$, the surgeon gave an inferior dental nerve block with local anesthetic 2\% lidocaine with 1:100000 epinephrine for the regional anesthesia. The surgical removal of the impacted mandibular third molar was then completed with a standardized technique by the same surgeon.

Demographics of the patients were recorded and a total number of 40 observations were performed.

\section{Assessments}

During the postoperative assessment of the patients, the level of pain was determined by using the Verbal Rating Scale (VRS) $(0=$ no pain, $5=$ worst possible pain). Pain perception was recorded at $15 \mathrm{~min}, 30$ min and 1,2, 4, 6, 12, 24 hour when the time of incision was considered the baseline. Moreover, the duration of the operation, the time to first analgesic requirement use, additional analgesic need of patients, patient and doctor satisfaction $(0=$ none, $1=$ moderate, $2=$ good $3=$ perfect), side effects such as nausea, vomiting, allergic reactions, were also deter- 
mined. Patients with moderate postoperative pain (VRS $\geq 3$ ) were given Diclophenac $\mathrm{Na} 75 \mathrm{mg}$ oral.

\section{Statistics}

All analyses were performed by SPSS version 15.0 software package. Changes in VRS pain scores were assessed by Wilcoxon signed-rank test, the global assessments were assessed by Chi-square statistic. A value of $\mathrm{p}<0.05$ was considered as significant.

\section{Results}

In the present study, a total number of 40 observations were carried out in 20 patients. There were no statistically significant differences in patient demographics and the duration of the operation between two groups (Table 1).

During the first 12 hours, the VRS values in DT Group were significantly lower than those of Placebo Group patients $(\mathrm{p}<0.05)$ (Figure 1). While the highest VRS value was determined to be during the 2nd hour in Placebo Group (5 \pm 1.6$)$, in DT Group patients, it was the highest during the 4th hour $(2.9 \pm 2.1)$. In Placebo Group, the first analgesic requirement time was significantly earlier than that in Group DT $(\mathrm{p}<0.05)$. Additional analgesic need of Placebo Group patients were significantly greater, when compared with the analgesic need of

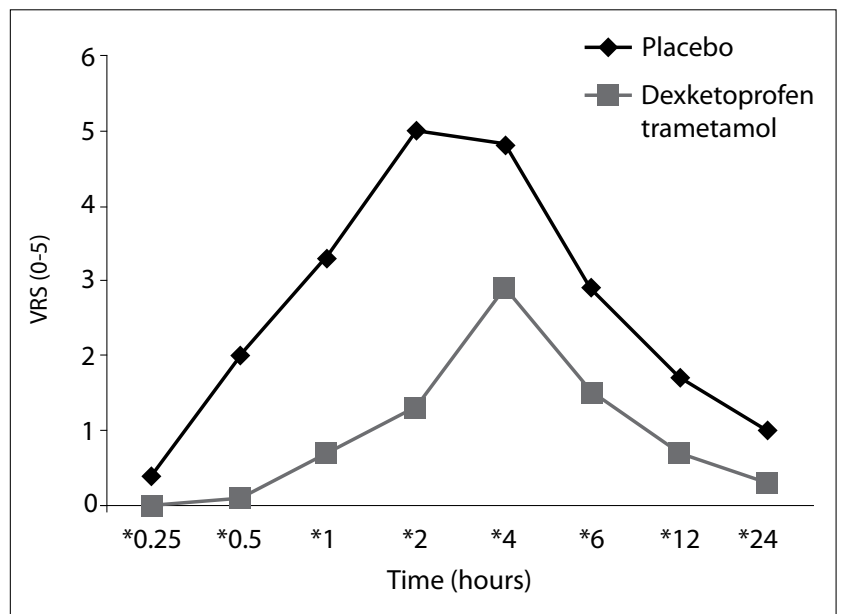

Figure 1.VRS score during the first 24 hours period after surgery placebo and dexketoprofen trametamol groups.

Group DT Group patients $(\mathrm{p}<0.05)$. Additional analgesic need occurred in 19 patients in Placebo Group, and 9 patients in DT Group . Among the DT Group patients, patient and physician satisfaction was greater, which was statistically significant $(\mathrm{p}<0.05)$ (Table 2).

\section{Discussion}

The surgical extraction of impacted mandibular third molars induces acute moderate to severe pain, and has been used as an excellent clinical trial model for pain studies. ${ }^{[1]}$

Table 1. Demographic properties and operation duration

\begin{tabular}{lccc}
\hline & Placebo $(\mathbf{n}=\mathbf{2 0})$ & & DT $(\mathbf{n}=\mathbf{2 0})$ \\
& Mean \pm SD & & Mean \pm SD \\
\hline Age (year) & $22.8 \pm 3.7$ & $22.8 \pm 3.7$ \\
Operation duration (min) & $12.2 \pm 4.6$ & $11.8 \pm 4.1$ \\
\hline DT: Dexketoprofen trometamol. & &
\end{tabular}

Table 2. Doctor and patient satisfaction for drugs

\begin{tabular}{|c|c|c|c|c|c|c|c|c|}
\hline & \multicolumn{4}{|c|}{ Doctor satisfaction } & \multicolumn{4}{|c|}{ Patient satisfaction } \\
\hline & \multicolumn{2}{|c|}{ Placebo $(n=20)$} & \multicolumn{2}{|c|}{ DT $(n=20)$} & \multicolumn{2}{|c|}{ Placebo $(n=20)$} & \multicolumn{2}{|c|}{ DT $(n=20)$} \\
\hline & $\mathbf{n}$ & $\%$ & $\mathbf{n}$ & $\%$ & $\mathbf{n}$ & $\%$ & $\mathbf{n}$ & $\%$ \\
\hline Moderate & 5 & 25 & 0 & 0 & 4 & 20 & 1 & 5 \\
\hline Good & 13 & 65 & 9 & 45 & 14 & 70 & 5 & 25 \\
\hline Perfect & 2 & 10 & 11 & 55 & 2 & 10 & 14 & 70 \\
\hline
\end{tabular}

DT: Dexketoprofen trometamol. 
Many factors in the postoperative pain resulting from surgical extraction relate to the peripheral inflammatory reaction initiated by surgical trauma. NSAID's are among the most widely used medications in the word because of their demonstrated efficacy in reducing pain and inflammation. By decreasing prosthoglandin production, NSAID's attenuate the response of the peripheral and central components of the nervous system to noxious stimuli.

Pre-emptive analgesia may be defined as an antinociceptive treatment that prevents establishment of altered central processing of afferent input from sites of injury. ${ }^{[12]}$

This property makes NSAID's ideal drugs to use in a preemptive analgesia. Therefore NSAID's have been reported to be effective for the pain after surgical extraction $^{[13,14]}$ and have been used for the effectiveness of preemptive analgesia concerning administration time in numerous reports. ${ }^{[12,15]}$

Pre- or postoperative administration of $550 \mathrm{mg}$ naproxen or $1.000 \mathrm{mg}$ diflunisal orally produces good pain relief after surgical removal of impacted third molars. However, no significant differences were found in either study about pain relief between the pre- and postoperative approaches. ${ }^{[16,17]}$ A study using preemptive analgesia showed that tramadol $50 \mathrm{mg}$ IV is more effective than oral tramadol 50 $\mathrm{mg}$ in relieving pain after third molar surgery. ${ }^{[18]}$ Another study demonstrated that ketorolac $30 \mathrm{mg}$ IV produces beter preventive analgesic efficacy than tramadol $50 \mathrm{mg}$ IV when administered preoperatively in third molar surgery. ${ }^{[19]}$

Although there have been some studies evaluating the efficacy of dexketoprofen for dental pain ${ }^{[8,20]}$ our study is the first clinical investigation to examine the analgesic effects of IV DT for preemptive analgesia for third molar surgery.

This study demonstrated that IV administration of DT showed clear differences in the need for postoperative analgesic consumption compared with the group receiving placebo. We found that only 9 patients in DT group needed medication within 12 hour after surgery compared with 19 patients from placebo group. We found statistically significant dif- ferences between groups in pain intensity measured by VRS at 12 hour postsurgery. However, it seems that this difference evaluated by itself does not have clinical significance for pain relief because of its subjective assessment; however, we consider the clear difference in analgesic consumption after treatment to be clinically relevant.

The study is show that, in patients undergoing removal of an impacted mandibular third molar, treatment with preemptive DT resulted in an important reduction in consumption of postoperative analgesics.

\section{Conclusion}

DT is more effective than placebo for using as preemptive analgesia for acute postoperative pain control in patients underwent removal of an impacted mandibular third molar.

\section{Conflict-of-interest issues regarding the author- ship or article: None declared.}

\section{Peer-rewiew: Externally peer-reviewed.}

\section{References}

1. de Sousa Santos JA, da Silva LC, de Santana Santos T, Menezes Júnior LR, de Assunção Oliveira AC, Brandão JR. Comparative study of tramadol combined with dexamethasone and diclofenac sodium in third-molar surgery. J Craniomaxillofac Surg 2012;40(8):694-700. CrossRef

2. Kara I, Tuncer S, Erol A, Reisli R. The effects of preemptive dexketoprofen use on postoperative pain relief and tramadol consumption. Agri 2011;23(1):18-21. CrossRef

3. Yazar MA, Inan N, Ceyhan A, Sut E, Dikmen B. Postoperative analgesic efficacy of intravenous dexketoprofen in lumbar disc surgery. J Neurosurg Anesthesiol 2011;23(3):193-7.

4. Kesimci E, Gümüş T, Izdeş S, Sen P, Kanbak O. Comparison of efficacy of dexketoprofen versus paracetamol on postoperative pain and morphine consumption in laminectomy patients. Agri 2011;23(4):153-9. CrossRef

5. lohom G, Walsh M, Higgins G, Shorten G. Effect of perioperative administration of dexketoprofen on opioid requirements and inflammatory response following elective hip arthroplasty. Br J Anaesth 2002;88(4):520-6. CrossRef

6. Pavelka K. A comparison of the therapeutic efficacy of diclofenac in osteoarthritis: a systematic review of randomised controlled trials. Curr Med Res Opin 2012;28(1):163-78.

7. Akural El, Järvimäki V, Länsineva A, Niinimaa A, Alahuhta S. Effects of combination treatment with ketoprofen $100 \mathrm{mg}$ + acetaminophen $1000 \mathrm{mg}$ on postoperative dental pain: a single-dose, 10-hour, randomized, double-blind, active- and placebo-controlled clinical trial. Clin Ther 2009;31(3):560-8.

8. Jiménez-Martínez E, Gasco-García C, Arrieta-Blanco JJ, Gomez del Torno J, Bartolome Villar B. Study of the analgesic efficacy of Dexketoprofen Trometamol 25mg. vs. Ibuprofen 
$600 \mathrm{mg}$. after their administration in patients subjected to oral surgery. Med Oral 2004;9(2):143-8.

9. Sánchez-Carpena J, Domínguez-Hervella F, García I, Gene E, Bugarín R, Martín A, et al. Comparison of intravenous dexketoprofen and dipyrone in acute renal colic. Eur J Clin Pharmacol 2007;63(8):751-60. CrossRef

10. Zippel $\mathrm{H}$, Wagenitz A. Comparison of the efficacy and safety of intravenously administered dexketoprofen trometamol and ketoprofen in the management of pain after orthopaedic surgery: A multicentre, double-blind, randomised, parallel-group clinical trial. Clin Drug Investig 2006;26(9):517-28.

11. Isiordia-Espinoza MA, Pozos-Guillén AJ, Martínez-Rider R, Herrera-Abarca JE, Pérez-Urizar J. Preemptive analgesic effectiveness of oral ketorolac plus local tramadol after impacted mandibular third molar surgery. Med Oral Patol Oral Cir Bucal 2011;16(6):776-80. CrossRef

12. Jung YS, Kim MK, Um YJ, Park HS, Lee EW, Kang JW. The effects on postoperative oral surgery pain by varying NSAID administration times: comparison on effect of preemptive analgesia. Oral Surg Oral Med Oral Pathol Oral Radiol Endod 2005;100(5):559-63. CrossRef

13. Fletcher MC, Spera JF. Management of acute postoperative pain after oral surgery. Dent Clin North Am 2012;56(1):95-111.

14. Michelet D, Andreu-Gallien J, Bensalah T, Hilly J, Wood C, Nivoche $Y$, et al. A meta-analysis of the use of nonsteroidal antiinflammatory drugs for pediatric postoperative pain. Anesth Analg 2012;114(2):393-406. CrossRef

15. Kaczmarzyk T, Wichlinski J, Stypulkowska J, Zaleska $M_{\text {, }}$ Woron J. Preemptive effect of ketoprofen on postoperative pain following third molar surgery. A prospective, randomized, double-blinded clinical trial. Int J Oral Maxillofac Surg 2010;39(7):647-52. CrossRef

16. Sisk AL, Mosley RO, Martin RP. Comparison of preoperative and postoperative diflunisal for suppression of postoperative pain. J Oral Maxillofac Surg 1989;47(5):464-8. CrossRef

17. Sisk AL, Grover BJ. A comparison of preoperative and postoperative naproxen sodium for suppression of postoperative pain. J Oral Maxillofac Surg 1990;48(7):674-8. CrossRef

18. Ong CK, Lirk P, Tan JM, Sow BW. The analgesic efficacy of intravenous versus oral tramadol for preventing postoperative pain after third molar surgery. J Oral Maxillofac Surg 2005;63(8):1162-8. CrossRef

19. Ong KS, Tan JM. Preoperative intravenous tramadol versus ketorolac for preventing postoperative pain after third molar surgery. Int J Oral Maxillofac Surg 2004;33(3):274-8. CrossRef

20. Jackson ID, Heidemann BH, Wilson J, Power I, Brown RD. Double-blind, randomized, placebo-controlled trial comparing rofecoxib with dexketoprofen trometamol in surgical dentistry. Br J Anaesth 2004;92(5):675-80. CrossRef 